\title{
Uncovering motives and rivalry of China-Australia amid the COVID-19 pandemic in the Pacific region
}

\section{Menyingkap motif dan rivalitas Tiongkok-Australia di tengah pandemi COVID-19 di kawasan Pasifik}

\author{
Aryo Bimo Prasetyo ${ }^{1 *}$, Achmad Ismail ${ }^{2}, \&$ Muhammad Fachrie ${ }^{2}$ \\ ${ }^{1}$ Department of International Relations, Faculty of Social \& Political Sciences, \\ University of Indonesia \\ ${ }^{2}$ Department of International Relations, Faculty of Social \& Political Sciences, \\ University of Jakarta \\ Address: ${ }^{1} J a l a n$ Prof. Dr. Selo Soemardjan, Depok, West Java, Indonesia 16424 \\ ${ }^{2}$ Jalan Pulomas Barat, East Jakarta, Jakarta Capital Special Region, Indonesia 13210 \\ Email: arbims1111@gmail.com
}

Article History: Received 20 August 2020; Accepted 18 October 2021; Published Online 29 November 2021

\begin{abstract}
The rivalry between China and Australia in the Pacific region shows high tension. This rivalry has increasingly intense in the form of providing assistance to deal with the COVID-19 pandemic, where both countries have various motives of interest by providing the assistance. This article aims to describe the economic and political motives of China and Australia in order to provide assistance in handling COVID-19 to countries in the Pacific region. This article used a descriptive method by collecting several sources from books, journals, official documents, and scientific articles on the internet. It finds that China and Australia have economic and political-security motives from the assistance provided to countries in the Pacific region. The large natural resources in the Pacific region and its transformation into a world maritime trade route become the economic motives. The political motives for China are the principle of "One China" and a "Good Image/Perception" for China, while the political motive for Australia is strengthening Australia's solidarity in the Pacific region. This article concludes that China's presence in the Pacific region, which includes assistance in combatting COVID-19 and other concerns, puts China a threat to Australia, making the rivalry between the two countries is no longer inevitable.
\end{abstract}

Keywords: COVID-19 assistance; economic motive; Pacific; political motive; rivalry of China-Australia

\begin{abstract}
Abstrak
Rivalitas antara Tiongkok dan Australia di kawasan Pasifik menunjukkan tensi yang tinggi. Rivalitas tersebut semakin intens dalam bentuk pemberian bantuan penanganan pandemi COVID-19, di mana di balik bantuan tersebut terdapat berbagai motif kepentingan baik dari Tiongkok maupun Australia. Artikel ini bertujuan untuk mendeskripsikan motif ekonomi dan motif politik Tiongkok dan Australia dalam memberikan bantuan penanganan COVID-19 kepada negara-negara di kawasan Pasifik. Artikel ini menggunakan metode penelitian deskriptif dengan mengumpulkan beberapa sumber dari buku, jurnal, dokumen resmi, dan artikel ilmiah di internet. Artikel ini menemukan bahwa ada motif ekonomi maupun politik-keamanan bagi Tiongkok dan Australia dalam memberikan bantuan bagi negara-negara di kawasan Pasifik. Sumber daya alam yang besar yang dimiliki kawasan Pasifik dan transformasinya sebagai jalur perdagangan maritim dunia menjadi motif ekonomi. Motif politik Tiongkok adalah prinsip "One China" dan "Good Image/Perception" bagi Tiongkok, sementara motif politik Australia adalah penguatan solidaritas Australia di kawasan Pasifik. Artikel ini menyimpulkan bahwa hadirnya Tiongkok di kawasan Pasifik dengan memberikan bantuan COVID-19 serta bantuan lainnya membuat Australia menjadikan Tiongkok sebagai ancaman, sehingga rivalitas Tiongkok dan Australia tidak lagi terelakkan.
\end{abstract}

Kata kunci: bantuan COVID-19; motif ekonomi; Pasifik; motif politik; rivalitas Tiongkok-Australia

\section{Introduction}

The terminology "the Rise of China" gives color and alters the international constellation (Ikenberry 2014, Morrison 2013). This is because China is progressing significantly in various fields. China's 
economy is undoubtedly the second-largest after the US by experiencing economic growth of 6.9 percent in 2017 (Hornby \& Wildau 2018). Therefore, China can free around 500 million of its citizens from poverty (Morrison 2013). In the defense sector, China has also increased its defense spending allocation by 8.1 percent since 2017 with a value of US \$ 175 billion (Rajagopalan 2018). Meanwhile, in the field of technology and innovation, the Chinese government has given increasing attention from time to time, even the most ambitious by allocating 20 percent or growing twice the rate of GDP growth per year since 2000 (Amighini 2019).

This reality has reaped many responses from other countries which have had an impact on changing the constellation of international politics. Some countries respond to this reality as a challenge while some even consider it a real threat to several countries, especially the US (Al Syahrin 2018, Ismail 2018) and its allies. For example, Australia has been considered "the Rise of China" as a threat for the last two decades (Goodman 2017). Another opinion suggests that Australia's response to "the rise of China" is a combination of accommodation and "soft balancing" (McDougall 2014). Of course, this is by considering the dynamics of US-China relations in the region which are sometimes cooperative or conflictual.

Australia's response to China shows that the rivalry between the two is inevitable, especially in the Pacific region. The Pacific region is becoming a pawn in the game of power politics among traditional and regional powers over recent years (Salem 2021). Historically, China's existence was identified during Deng Xiaoping's leadership, which was considered by the Prime Minister of New Zealand, Robert Muldoon, as a form of balancing the presence of the Soviet Union, a close ally of China. Non-binding economic assistance and easy requirements are the main attraction for countries in the Pacific (Yang 2009), in addition to educational assistance, student exchanges, and Mandarin language training. Furthermore, China carries out its policy of Peaceful Development, which becomes a weapon for China to help other countries, especially in the Pacific, with development assistance. This assistance has continued and even increased compared to previous years with the Belt Road Initiative (BRI) policy initiated by China. The presence of China in the Pacific region makes a threat to Australia even greater. This is because since its establishment to these days, Australia has considered the Pacific region as "sub-imperialism" (El-Haq \& El-Islam 2020). Therefore, the political, economic, and natural resource relations between Australia and the Pacific countries are a consequence of the policy of "sub-imperialism". In other words, Australia becomes the country that dominates the Pacific region. Since the early 1990s, the Australian government has sought to use aid as a "carrot and stick" to push for domestic governance reforms in Pacific island nations that their governments often do not want. This is done by Australia in order to minimize the risk of possible threats to Australia which are influenced by the possibility of countries in the Pacific region becoming failed countries. Therefore, Australia decided to continue to help these countries to develop and meet the predominant need for assistance to establish good governance (Hameiri 2018). It is clear that China's existence in the Pacific region has reduced its role and position of leadership as well as a threat to Australia in the region (Wallis 2012, Hegarty 2015). A rivalry that focuses more on the Pacific region, not only limited to regional issues, sometimes touches global issues. Not only on traditional issues (such as security, military, and border issues) but also non-traditional issues such as the current issue of the COVID-19 pandemic.

Briefly, Novel Coronavirus Disease 2019, or what is called COVID-19 originated from an animal market in Wuhan, Hubei Province, China. Based on unpublished media reports by the Chinese government, the first cases of COVID-19 were tracked on November 17, 2019, with the identification of 266 people infected with COVID-19 (Davidson 2020). The Chinese government assumes that this virus will not spread and will remain in Wuhan. However, the increase in people infected with this virus is beyond predictions and indicates a serious escalation. The spread of this virus is not only across provinces but across countries. As of June 24, 2020, Worldometers data shows that there are around 9,383,234 positive cases of COVID-19, 480,423 deaths, and 5,070,377 confirmed cured cases (Worldometers 2020). The World Health Organization (WHO) estimates that the end of COVID-19 cannot be ascertained and even predicts that it will continue to spread. Meanwhile, on June 24, 2020, the Pacific region recorded a total 
of 9,145 positive cases of COVID-19, 125 deaths, and 8,505 confirmed cured cases (Worldometers 2020). The number of positive cases is quite high, where countries in the Pacific region have poor health facilities in terms of technology, human resources, and so on. Therefore, it is quite natural that countries in the Pacific region are worried about the impact of the COVID-19 pandemic on their citizens and cannot completely depend on one country to help them, in this context is Australia.

The tension of rivalry between China and Australia is getting higher during the COVID-19 pandemic. Not long ago, China assisted countries in the Pacific region to test kits and protective equipment worth US \$ 1.9 million (Needham 2020). This condition is increasingly favorable for China, because so far, countries in the Pacific region such as New Caledonia, French Polynesia, Fiji, and Guam have to send specimens to Australia and New Zealand to see the results of these specimen tests, which of course, has become ineffective and inefficient. Not to mention that several countries in the Pacific region such as Papua New Guinea, Solomon Islands, Kiribati, Kaaro Neeti, Vanuatu, Tonga, and French Polynesia are waiting for assistance from China to arrive which previously promised long-distance assistance of experts of Chinese medicine in Beijing for health officials from 10 Pacific countries. China's assistance to the region which began in late March, of course, "shocked" the Australian government while at the same time also worrying the Chinese government that it might succeed to overcome it. Seeing this reality, Australia is increasingly concerned and at the same time sees that what China is currently doing is a real threat to the power that Australia has in the Pacific region. Not standing still, Australia responded to this by assisting Pacific countries both in finance and medical equipment. The Minister for the Pacific and International Development of Australia said that Australia will help move more important medical equipment to Pacific countries to help them prepare for COVID-19 as well as prioritize any aid funds available to the Pacific to be channeled immediately into the health issue and the COVID-19 issue. (Graue 2020). In May 2021, the Chinese COVID-19 vaccine has been launched in the Pacific, with the Deputy Prime Minister of Solomon Islands receiving the first Sinopharm shot in the region (Wasuka 2021) as part of China's efforts to help the Pacific country in dealing with COVID-19. However, previously Prime Minister Scott Morrison's government has promised to supply its neighbors with COVID-19 vaccines in 2021 as part of a $\mathrm{A} \$ 500$ million package aimed at achieving "full immunization coverage" in the region (Scott 2021). It seems that China and Australia are doing the same attempt by providing medical aid and financial assistance.

In other words, the competition between China and Australia is cross over time and issues and has impacts on several sectors. Recently, Australia has appealed to the international community to carry out the origins of COVID-19 which has harmed the world and the cause is thought to be due to the negligence of the Chinese government. China lowered tariffs on Australian beef imports, indicating a trade war. Its citizens will temporarily stop going to Australia because of Australian racism against Chinese citizens, as there is no guarantee of when the country will send aid. In dealing with COVID-19, do not expect an imbalance or something the country wants to aim at.

The description above explains that the current condition of the COVID-19 pandemic is not only treated as a mere health problem both globally and in the Pacific region, but the presence of China and Australia makes the COVID-19 case seem to be a "stage" for rivalry for the power of the two. Besides, there are motives for disbursing aid to the Pacific region. This raises an interesting question, "what are the motives for China and Australia to assist in handling COVID-19 in the Pacific region, and how is the rivalry between the two?" Therefore, this article argues that there are economic, political, and security motives for China and Australia by providing assistance to countries in the Pacific region. The existence of differences or contradictions between the motives brought by China and Australia causes the tension of their rivalry to increase, even impacting other issues, such as trade wars, increased acts of racism, and so on.

This article attempts to comprehensively analyze some of the assistance provided by China and Australia for the handling of the COVID-19 pandemic in the Pacific region. Then, this article analyzes the economic and political security motives by China and Australia in providing this assistance in the 
Pacific region. This is because the Pacific region has a strategic location that is also supported by the natural resources contained in the area. Therefore, the opposing motives make the rivalry between the two in the Pacific region real, sustainable, and have a wide spill-over effect.

\section{Research Method}

This article employed the qualitative research method of descriptive-analytical. The descriptiveanalytical method serves to describe or provide an overview of the object under study through data or samples that have been collected as they are and make conclusions that apply to the public (Sugiyono 2009).

The data analysis technique used was firstly collecting all data from various references, such as books, journals, official documents, and scientific articles on the internet related to the motives of China and Australia in helping Pacific countries in dealing with the COVID-19 pandemic. Then, some of the data that has been collected is simplified as well as classified, so that the reference is then reduced/ selected on the data that is needed and not in this article. After that, the data that has been selected is compiled to support the analysis to make it easier to understand systematically, making it easier to find the relationship between similarities and differences to produce a conclusion as an answer to the existing problem formulation. The time limit for the research in this article is the period following the outbreak of the COVID-19 pandemic, especially when China and Australia actively provided humanitarian assistance to countries in the Pacific region as a form of rivalry between the two countries.

\section{Results and Discussion}

The COVID-19 pandemic has overwhelmed many countries to control it. The reason for this is that the COVID-19 pandemic had ramifications in various fields of socio-economic life, and many people died as a result of the pandemic. It gives a major impact, especially when this pandemic hit developing countries, such as countries in the Pacific region. Apart from the vulnerable economy, the health technology to control the COVID-19 pandemic is still lacking. Therefore, it is fairly uncommon for countries in the Pacific region to require financial and medical assistance from other countries to help control the COVID-19 pandemic. This is what other countries are trying to fulfill, including China and Australia.

China is stepping up its efforts to assist countries in the Pacific region to control the COVID-19 pandemic. China is preparing the US $\$ 1.9$ million in aid to countries in the Pacific region in the form of test kits and personal protective equipment. Besides, it has also handed over 47 special military vehicles to Fiji as a means of distributing aid (Swami 2020), the US \$100,000 assistance for Vanuatu, US \$200,000 for Tonga (Powles 2020), 2,000 test kits and face masks for Papua New Guinea, US \$300,000 for the Solomon Islands, and thousands of face masks for Kiribati (Needham 2020). Furthermore, China participated in providing experience as well as training in handling the COVID-19 pandemic to countries in the Pacific region via video conference. As a result, the country of Samoa reported no additional positive cases of COVID-19 on April 26, 2020, and thanked China for all assistance to Samoa.

Seeing China move quickly in providing COVID-19 assistance in the Pacific region has Australia, a country that has long had the power, concerned. Australia also believes that it should pay more attention to the Pacific region, which so far has received less attention due to the focus on Iraqi territory. Australia also moved quickly by assisting countries in the Pacific region. Australia is spending US \$ 100 million on a "quick financial support" package to help 10 Pacific nations meet their country's basic operating costs. Papua New Guinea will receive the US \$ 20.5 million with the Solomon Islands and Vanuatu receiving US \$ 13 million, Timor-Leste receiving US \$ 10 million, Fiji, Samoa, and Tonga receiving US $\$ 10.5$ million each, Nauru and Kiribati receiving about US \$ 10 million each, and Tuvalu receiving 4.5 million \& \$ 3 million (Clarke 2020). Also, Australia launched the "Pacific Humanitarian Pathway on COVID-19" policy consisted of 3 phases of assistance starting from immediate humanitarian assistance, 
economic recovery, then building resilience (Conroy 2020). Australia has also extended financial loans from several countries in the Pacific region as well as a 12-month visa extension for workers from the Pacific region, especially since this region relies on the tourism sector.

\section{Economic motives of China and Australia}

The assistance provided by China and Australia above becomes interesting when the two countries have certain motives they want for assisting in handling COVID-19 in the Pacific region. China and Australia that came with the help of the COVID-19 pandemic have economic motives behind them. There are several important reasons behind the assistance provided. The first is natural resources. Many islands in the Pacific region are rich in natural resources, such as timber, minerals, and fish (Hollingsworth 2019). By examining it more deeply, several countries in the Pacific region have abundant oil and gas reserves, for example, Timor Leste has oil and gas in the Greater Sunrise block with potential oil reserves worth US $\$ 50$ billion, while Papua New Guinea (PNG) has resources of mineral, gold, and oil, gas, as well Vatukola mining area, Fiji has gold and silver added with an estimated 26,000 kg of gold (El-Haq \& El-Islam 2020). Therefore, the Pacific region with its rich natural resources has become a contestation of the influence of China and Australia. The wealth of natural resources becomes important when it becomes a source of raw materials for production by China and Australia.

One of the importance of the Pacific region for China is the source of raw materials for Chinese production, such as agricultural products in the form of palm oil, copra, coconut oil, vanilla, coffee, and cocoa. China has gone further by proving its presence through various investments, especially those in the mining, coal, oil, and gas sectors. It is noted that since 2011, Beijing has expanded more in Papua New Guinea (PNG) which is home to gold, nickel mines, liquefied natural gas, and timber forests. PNG's Ramu Nickel Mine is owned by a company from China, namely Metallurgical Corporation of China Limited (MCCL). Almost 80\% of the shares of PNG's Pacific Ocean Industry Zone are owned by Eximbank China, while Fiji's Bua Bauxite Mine is owned by Exploration company of Aurum Xinfa China. Furthermore, $50 \%$ of the shares of PNG Porgera Gold Mine are owned by China's Zerjin mining group and the Frieda River gold and copper prospect in PNG is an 80:20 joint venture between PanAust China and Junior Highlands Pacific (McCarthy 2016). Meanwhile for Australia, natural resources and energy in the Pacific region are also quite important for Australia. It is evidenced by verification as one of the focuses of Australian investment in the Pacific region.

It seems that the wealth of natural resources in the Pacific region is very attractive to superpower countries. Anthony (1990) said that in terms of natural resources, the Pacific region has long been a 'stage' for the struggle for natural resources for countries in the region and superpower countries that are fighting for control over the Pacific region (Anthony 1990). Consequently, at least both China and Australia are aggressively providing COVID-19 assistance to countries in the Pacific region because they have interests of in terms of natural resources. In the sense that, when China and Australia assist in handling the COVID-19 pandemic, other things can be obtained through natural resources by the two countries. At least, they can secure their investment in the area in the natural resources sector, ensuring that it continues.

The second important reason for China and Australia to assist in handling the COVID-19 pandemic is that the region is a strategic maritime trade route. When looking at geographic conditions, the Pacific region is a hub or trade hub between countries in the north (Western Europe, North America, East Asia, etc.) to countries in the south (Australia, New Zealand, and countries in the Pacific region) and vice versa. The Pacific region is an alternative to Indonesia that has three Indonesian Archipelago Sea Lanes (ALKI) which are also international trade routes from countries in the north to the south and vice versa. Also, this region is quite important for the trade of countries in the Pacific region that have more than 90 percent of the trade supplying important goods and commodities, such as food, fuel, building materials, and vehicles, and to provide access to international markets for export (Suva 2016). For additional information, based on data from Statista, over 25 million twenty-foot equivalent units (TEU) of cargo 
are expected to be transported across the Pacific Ocean in 2020, making Trans-Pacific routes the largest shipping zone in terms of load size (Statista Research Department 2021). Besides, the Pacific region becomes a secondary route as well as a secondary checkpoint for international trade as shown in Figure 1.

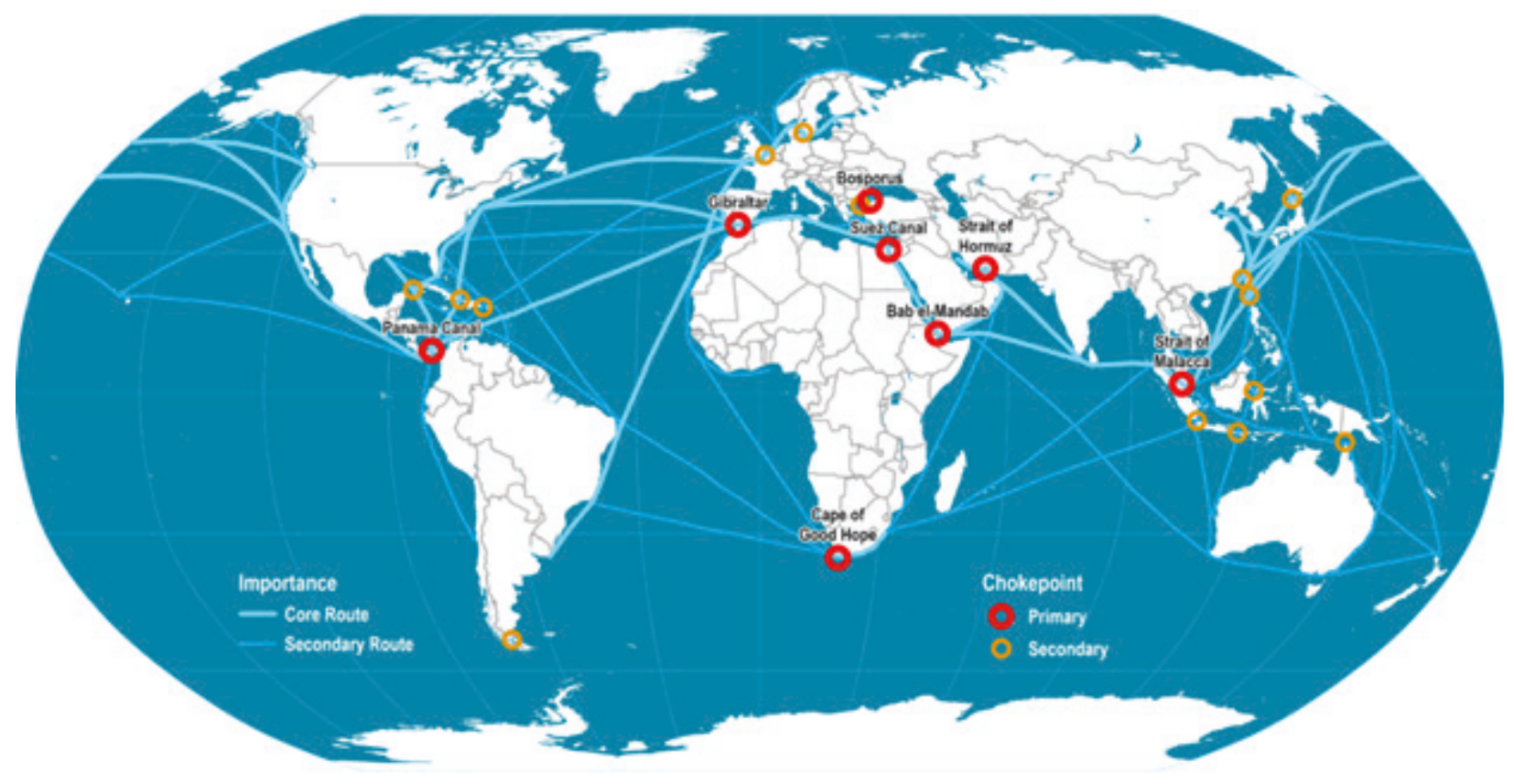

Figure 1.

World maritime trade rosute Source: Notteboom \& Rodrigue (2021)

For China, engagement efforts carried out through assisting in handling COVID-19 in the Pacific region are important to see that this region has a strategic maritime trade route. Historically, the trade route in the Pacific islands has been the oldest and functional route for the silk road for China. Now several countries are becoming interested in this silk trade route (marineinsight.com 2019). The existence of this strategic maritime trade route has made the growth of two-party trade significant. It was noted that the trade value in 2014 was US \$ 4.5 billion and increased to US \$ 7.5 billion. Meanwhile, for Australia, the Pacific region is no less important for its maritime trade routes. At least three of Australia's five major maritime trade routes must pass through the Pacific islands. It is noteworthy that these three trade routes play an important role of around 45 percent for Australia's maritime exports as evidenced in 2016-2017 that amounted to around \$ 103 billion or about 6 percent of Australia's GDP (Colton 2018). Therefore, the protection of maritime trade routes is a crucial part of the national interests of China and Australia, and it is not uncommon for the two countries to put it in their respective Defense White Paper.

The existence of maritime trade routes in the Pacific region is increasingly real and important. Needham (2020) stated that the Pacific islands have grown as a strategic priority for China and the United States and its allies, including Australia, who want to regulate relations with countries that control strategic air routes for trade. In the context of providing COVID-19 assistance, it can be said that this action is an effort to enlarge their strength. The disposal is also to secure maritime trade routes which are important for the two countries in terms of trade value and the strategic location of the Pacific region for trade. As a result, this assistance is not only limited to trade but also gives confidence in the Pacific countries, allowing both parties to expand their trading activities. Another fact from the Lowy Institute states that China has become the second-largest donor in the Pacific after Australia.

\section{Political security motives of China and Australia}

Another motive of China and Australia for providing COVID-19 assistance to countries in the Pacific region is the political security motive. There are several important reasons for China and Australia 
behind providing COVID-19 assistance to countries in the Pacific region. First, for China, this is a momentum to spread the principle of "One China" in the Pacific region. At the meeting between the Chinese government and countries in the Pacific region virtually, China will continue to support Pacific island countries in their fight against COVID-19 and expand measurement in various fields after the pandemic. However, the interesting thing is that they also voiced their stern opposition to Taiwan's practices of politicization, stigmatization, and virus labeling, reaffirm their strong support for the "One China" principle and hope their comprehensive strategic partnership with China will be lifted to new heights (Xinhua 2020). The principle of "One China" is that there is a recognition of one China, not two as has so far been adhered to by Taiwan. China considers that Taiwan is not a country that has its sovereignty but is an integral part of China. The relationship between the principle of "One China" and the presence of China in the Pacific is about how China maintains relations with countries that are already affiliated with Taiwan. China tries to make various approaches to Pacific countries that can be in the form of economic assistance, investment, or other things. One of the results of this policy was the recognition of China as "One China", not Taiwan.

The second political security motive is to assist in handling COVID-19 in the Pacific region, which has implications for the good image/perception of countries in the region towards China and Australia. For China, this is very important, because the growing issue is that China is the source of the COVID-19 virus. It is important to know that the COVID-19 pandemic has had a major impact on the perspective of other countries on China, none other than this is due to the initial emergence of this pandemic which originated in China, and how China handled the crisis conditions. Many countries accuse China on several occasions trying to cover up the development of the situation, both the condition of the victims, the number of victims, to the handling and manufacture of vaccines. This condition is exacerbated by restrictions on information, so that other countries cannot get complete information about conditions in China because this condition concerns other countries whose citizens are affected by the Covid-19 pandemic.

China's efforts to improve its image internationally due to the COVID-19 pandemic include issuing a white paper on China's response to the COVID-19 pandemic and providing assistance to countries that need medical equipment and funds to deal with this pandemic. President Xi Jinping called for a global campaign to fight COVID-19, assist other countries or related international organizations in dealing with COVID-19, and help report on the economic sectors that have been heavily impacted by this pandemic. China also wants to build a global community regarding health, especially in dealing with a pandemic at a global level, it also requires cooperation between countries to deal with COVID-19. China also conducts international cooperation and exchanges that support this problem, such as information exchange and cooperation in research to resolve this crisis. This is supported by various policy steps that have been implemented by China, such as the promotion of President Xi Jinping in international cooperation, information sharing and handling related to COVID-19, application of humanitarian assistance to the international community, provision of protective equipment for the international community, and cooperation in scientific (The State Council Information Office of the People's Republic of China 2020).

In the COVID-19 pandemic, China has also been seen actively using social media Twitter to support their national interests, such as efforts to form a positive image and refute the narrative that their country is the source of the outbreak (Triwibowo 2020). This is done to support China's global campaign and change perceptions that China is the country causing this pandemic. Moreover, China's belief in digital diplomacy is believed to help improve China's position at the global level. The existence of an official Chinese government Twitter account is also expected to eliminate the stigma that China is a rigid and closed country, and is internationally responsible for solving the problem of the COVID-19 pandemic. The presence of China to help countries in the Pacific can be said to improve diplomatic relations between countries but can be interpreted as China's attempt to remove the stigma as a country that spreads the pandemic. China embraces various countries in the Pacific by conducting video conferences between health ministers of China and Pacific countries during the pandemic and enhancing bilateral relations. In the private sector, Chinese companies that are involved in regional infrastructure projects 
are now branching out to supply medical equipment. This gesture of goodwill aims to improve the image of companies and governments at a time of growing criticism that censorship in China is delaying an immediate global response to the pandemic (Maclellan 2020).

No less important than China, for Australia, a good image or perception in front of the countries of the Pacific region is an important momentum. The reason for this is the good perception of Australia on the extent of Australia's solidarity with countries in the Pacific region. Australia as the largest country in the Pacific region should assist countries in the region. This assistance can be interpreted as international solidarity between countries in the region considering that COVID-19 is a pandemic that is spreading at the global level, thus assisting countries that need what should be done. This is because Australia has never focused itself on countries in the Pacific region, plus what happened was that PM Scott Morrison insulted Pacific countries by imposing Australian policies on countries in the Pacific region (Nursalikah 2019).

It seems that the struggle for a positive image in front of countries in the Pacific region is important for China and Australia. To achieve this, the two countries have shown high loyalty by assisting in handling COVID-19. This momentum was taken advantage of by China and Australia, where both countries have similar goals but with different histories. China feels the need to help the international community, especially the Pacific region, to change China's reputation as a cause of COVID-19 but also a solution to the problem of COVID-19. Meanwhile, Australia considers that countries in the Pacific region have long been strategic partners, so this pandemic has tested the level of solidarity with the partner's strategy that has been built for a long time.

\section{Rivalry between China-Australia}

In the context of the COVID-19 pandemic, the high tension from the rivalry between China and Australia is very real. This is based on the struggle for power over the Pacific region, conflicting economic and political motives, all of which culminate in securing each other's national interests. China is moving quickly in providing COVID-19 assistance in the form of financial assistance, medical devices, soft loans, and so on in the Pacific region and is well received by countries in the Pacific region. Facing the impact of the COVID-19, China's cooperation with Pacific island countries in public health is also strengthening. China has assisted the region with many urgently needed materials in the COVID-19 fight and has offered to donate COVID-19 vaccines to countries, such as Fiji and Solomon Islands (Sheng 2021). The presence of this assistance worries Australia as a strategic partner in the Pacific region. Australia also provides financial assistance, laboratories, medical equipment, health expertise, public information campaigns, and support for WHO's national preparedness plans and regional plans. Australia has renewed its focus on foreign aid for handling COVID-19 by including the Pacific region as a "first-tier priority" (Clarke 2020).

The presence of Chinese assistance in the Pacific region has threatened the Pacific regional democratic institutions initiated by Australia. Before the pandemic, Australia was in the process of institutionalizing significant changes to its foreign policy approach in the Pacific framed as Australia's deepening engagement efforts in the Pacific and assistance to the Australian Infrastructure Financing Facility for the Pacific (AIFFP) worth AU \$ 2 billion (Citowicki 2020). This COVID-19 pandemic assistance is a threat to democratic institutions in the Pacific region that have long been initiated by Australia, especially since democracy in the Pacific is still classified as very fragile. On the other hand, it seems that the COVID-19 pandemic assistance has an increasingly high tension in the rivalry between China and Australia. It is because China opened a new embassy in Kiribati after Kiribati received COVID-19 assistance and transferred its diplomatic recognition from Taiwan to China. Also, China will build a "small Singapore" area on Efate Island, Vanuatu. In an area of 86 hectares, infrastructure, apartments, villas, and shopping centers are built. With the establishment of the Chinese embassy in Kiribati and the construction of a "small Singapore" in Vanuatu, the rivalry in the Pacific, which has been controlled by Australia, now faces a new dimension with the presence of China. 


\section{Conclusion}

The conditions of the COVID-19 pandemic that have hit the entire world, demand solidarity between countries internationally to help each other. Assistance in the form of financial assistance and medical equipment are provided by China and Australia in the Pacific region. The two countries helped countries in the Pacific region to survive the COVID-19 pandemic, but in its development, the assistance provided by China and Australia had economic and political motives. The two countries are trying to realize their respective national interests in the Pacific region with various efforts made, thus causing a struggle for influence in the Pacific region.

The Pacific region itself is considered a strategic area for the national interests of the two countries, which is believed by controlling the region to increase the influence they have one another. Australia, as a partner that has been working with the Pacific for a long time, is disturbed by the presence of China which seeks to increase its influence through its various instruments, resulting in the rivalry between the two countries.

\section{References}

Al Syahrin MN (2018) China versus Amerika Serikat: Interpretasi rivalitas keamanan negara adidaya di kawasan Asia Pasifik. Journal Global \& Strategis 12 (1):145-163. https://doi.org/10.20473/ jgs.12.1.2018.145-163.

Amighini A (2019) China's Race to Global Technology Leadership. Milan: Ledizioni Ledi Publishing.

Anthony JM (1990) Conflict over Natural Resources in the Pacific. In: Ghee \& Valencia. Conflict over Natural Resources in South-East Asia and the Pacific. New York: Oxford University Press.

Citowicki P (2020) COVID-19 escalates the China-Australia contest in the Pacific. [Accessed 19 July 2020]. https://thediplomat.com/2020/04/covid-19-escalates-the-china-australia-contest-in-thepacific/.

Clarke M (2020) Australia spends \$100m in 'quick financial support' for Pacific countries hit by cyclone and pandemic. [Accessed 16 July 2020]. https://www.abc.net.au/news/2020-05-20/australiafinancial-support-pacific-governments-cyclone-pandemic/12262328.

Colton G (2018) Australia's alarm at Chinese base in the Pacific is justified. [Accessed 19 July 2020]. https://www.afr.com/opinion/australias-alarm-at-chinese-base-in-the-pacific-is-justified20180420-h0z0v6.

Conroy P (2020) Australia needs a comprehensive plan for Covid-19 in the Pacific. [Accessed 16 July 2020]. https://www.lowyinstitute.org/the-interpreter/australia-needs-comprehensive-plan-covid19-pacific.

Davidson H (2020) First Covid-19 case happened in November, China government records show report. [Accessed 25 April 2020]. https://www.theguardian.com/world/2020/mar/13/first-covid19-case-happened-in-november-china-government-records-show-report.

El-Haq MN \& El-Islam MS (2020) Australia sebagai kekuatan regional dalam eksploitasi sumber daya alam di kawasan Pasifik. Indonesia Journal of International Relations 4 (1):49-68. https://doi. org/10.32787/ijir.v4i1.117.

Goodman D (2017) Australia and the China threat: Managing ambiguity. The Pacific Review 30 (5):769782. https://doi.org/10.1080/09512748.2017.1339118.

Graue C (2020) Australia promising more for its Pacific COVID-19 response. [Accessed 25 June 2020]. https://www.abc.net.au/radio-australia/programs/pacificbeat/australia-promising-more-for-itspacific-covid-19-response/12117320.

Hameiri S (2018) China's Pacific presence improves Australian aid. Lowy Institute, 22 June. [Accessed 27 June 2020]. https://www.lowyinstitute.org/the-interpreter/china-pacific-presence-improvesaustralian-aid.

Hegarty M (2015) China's growing influence in the South-West Pacific: Australian policies that could respond to China's intentions and objectives. [Accessed 27 June 2020]. https://www. realcleardefense.com/articles/2018/02/27/protecting_the_south_pacific_113121.html. 
Hollingsworth J (2019) Why China is challenging Australia for influence over the Pacific Islands. [Accessed 27 June 2020]. https:/edition.cnn.com/2019/07/22/asia/china-australia-pacificinvestment-intl-hnk/index.html.

Hornby L \& Wildau G (2018) China's 2017 economic growth fastest in two years. [Accessed 22 June 2020]. https://www.ft.com/content/9bf532a8-66de-37bf-b515-03589957ada4.

Ikenberry J (2014) The Rise of China and the Future of Liberal World Order. London: Chatham House the Royal Institute of International Affairs.

Ismail A (2018) Motive and rivalry of superpower countries: The United States and China in Rohingya humanitarian crisis. Jurnal Hubungan Internasional 7 (1):107-117. https://doi.org/10.18196/ hi.71129.

Maclellan N (2020) Geopolitics meets pandemic in the Pacific. [Accessed 14 July 2020]. https:// insidestory.org.au/geopolitics-meets-pandemic-in-the-pacific/.

Marineinsight.com (2019) Maritime Silk Routes- The story of the oldest trade routes. Marine Insight, October 2019. [Accessed 14 July 2020]. https://www.marineinsight.com/maritime-history/ maritime-silk-routes-the-story-of-the-oldest-trade-routes/.

McCarthy J (2016) China extends its influence in the South Pacific. [Accessed 17 July 2020]. https:// www.abc.net.au/news/2016-09-10/china-extends-its-influence-in-the-south-pacific/7812922.

McDougall D (2014) Australian strategies in response to China's rise: The relevance of the United States. Asian Survey 52 (2):319-342. https://doi.org/10.1525/AS.2014.54.2.319.

Morrison WM (2013) China's Economic Rise: History, Trends, Challenges, and Implications for The United States. Washington, DC: Congressional Research Service.

Needham K (2020) China and Australia target Pacific with coronavirus aid. [Accessed 24 June 2020]. https://www.reuters.com/article/health-coronavirus-pacific/china-and-australia-target-pacificwith-coronavirus-aid-idUSL4N2BP1IT.

Notteboom PA \& Rodrigue JP (2021) Port Economics, Management and Policy. New York: Routledge.

Nursalikah A (2019) PM Fiji tuduh PM Australia hina negara Pasifik. [Accessed 19 July 2020]. https:// republika.co.id/berita/pwdjre366/pm-fiji-tufuh-pm-australia-hina-negara-pasifik.

Powles A (2020) COVID-19 and geopolitics in the Pacific. East Asia Forum, April 04. [Accessed 24 June 2021]. https://www.eastasiaforum.org/2020/04/04/covid-19-and-geopolitics-in-the-pacific/.

Rajagopalan RP (2018) China's 2018 military budget: New numbers, old worries. [Accessed 22 June 2020]. https://thediplomat.com/2018/03/chinas-2018-military-budgetnew-numbers-old-worries/.

Salem S (2021) China-US power politics in the Pacific, 23 July. [Accessed 02 July 2021]. https://www.eir.info/2020/07/23/china-us-power-politics-in-the-pacific/.

Scott J (2021) Australia's influence in Pacific Islands grows as China's wanes, 4 January. [Accessed 27 June 2020]. https://www.bloomberg.com/news/articles/2021-01-03/australia-makes-gains-inpacific-islands-as-covid-hinders-china.

Sheng Q (2021) Tearing up BRI deal will hit Australia's influence in South Pacific. Global Times, 1 May. [Accessed 27 June 2020]. https://www.globaltimes.cn/page/202105/1222551.shtml.

Statista Research Department (2021) Maritime trade routes - containerized cargo flows 2020. Statista, 23 February, 2021. [Accessed 18 June 2021]. https://www.statista.com/statistics/253988/estimatedcontainerized-cargo-flows-on-major-container-trade-routes/.

Sugiyono (2009) Metode Penelitian Pendidikan Pendekatan Kuantitatif, Kualitatif, dan R\&D. Bandung: Alfabeta.

Suva (2016) Pacific highlights shipping as lifeline on World Maritime Day 2016. [Accessed 19 July 2020]. https://www.spc.int/updates/news/2016/09/pacific-highlights-shipping-as-lifeline-onworld-maritime-day-2016.

Swami N (2020) China donates 47 specialised military vehicle to Fiji. [Accessed 10 July 2020]. https:// www.fijitimes.com/china-donates-47-specialised-military-vehicles-to-fiji/.

The State Council Information Office of the People's Republic of China (2020) Fighting Covid-19 China in Action. http://www.scio.gov.cn/zfbps/32832/Document/1681809/1681809.htm.

Triwibowo A (2020) Diplomacy and Covid-19: A reflection. Jurnal Ilmiah Hubungan Internasional, 1-10. https://doi.org/10.26593/jihi.v0i0.3861.103-112. 
Wallis J (2012) The dragon in our backyard: The strategic consequences of china's increased presence in the South Pacific. [Accessed 22 June 2020]. http://www.aspistrategist.org.au/the-dragon-inourbackyard-the-strategic-consequences-of-chinas-increasedpresence-in-the-south-pacific/.

Wasuka E (2021) China's sinopharm COVID-19 vaccine launches in the Pacific. ABC News, 21 May. [Accessed 27 June 2020]. https://www.abc.net.au/news/2021-05-21/pacific-nations-to-roll-outchinese-made-covid-19-vaccinations/100151672.

Worldometers (2020) Reported cases and deaths by country, territory, or conveyance. [Accessed 24 June 2020]. https://www.worldometers.info/coronavirus/\#countries.

Worldometers (2020) Covid-19 coronavirus pandemic. [Accessed 24 June 2020]. https://www. worldometers.info/coronavirus/.

Xinhua (2020) China, Pacific Island countries hold video meeting on anti-COVID-19. XinhuaNet, 14 May. [Accessed 19 July 2020]. http://www.xinhuanet.com/english/2020-05/14/c_139054505. htm.

Yang J (2009) China in the South Pacific: Hegemony on the horizon? The Pacific Review 22 (2):139158. https://doi.org/10.1080/09512740902815292. 